Interface / Koppelvlak

\section{'We are not a society of saints'}

\section{D.A. Etheredge}

Institute of Internal Auditors, South African Chapter, President, S.Afr. Institute of Management Accepted May 1983

In this article, the author illuminates the phenomena of corruption in the South African society. Not only does he illustrate that corruption needs to be contained, but he also suggests that companies, large and small, public and private are not doing enough to minimize the incidence of corruption.

The author then proceeds to scrutinize four ways of restrict. ing corruption:

- Legislation. Although he does not favour the option of legislation. he demonstrates that the introduction in the USA of the Foreign Corruption Practices Act led to substantial changes in company behaviour and practice.

- Behaviour. The author suggests that companies spell out in clear terms what is considered acceptable and legitimate behaviour and what is not. These policy guidelines must then be implementable in practice.

- Education. In the long term, the author suggests, society must be educated and reeducated in business ethics. Clearly, business schools would be the ideal instrument to carry the awareness into the business community.

- Audit. The author proposes that the audit is the best way of dealing with corrupt practices. Mangement must install the systems and internal controls; and must ensure that the internal audit team is composed of high quality people who will not deviate from their task objective. In this respect the computer - despite its own security problems - could be of great importance.

S. Atr. J. Bus. Mgmt. 1983, 14: 125-129

In hierdie artikel word die phenomeen van korrupsie in die Suid-Afrikaanse besigheidswêreld ontbloot. Die skrywer stel dit dat maatskappye en instansies nie genoeg doen om die pro. bleem te bekamp nie.

Die skrywer stel basies vier wyses voor waarvolgens korrupsie beheer kan word, nl. Wetgewing, Gedragskodes, Opvoeding en die Interne Oudit. Die skrywer slaan die laaste wyse hoogste aan en brei daarop uit - veral ten opsigte van die gebruik van die rekenaar.

S.Afr. Tydskr. Bodryfsl. 1983, 14: $125-129$

Time magazine recently nominated the Computer 'Man of the Year for 1982' thus confirming an uneasy feeling amongst its readers that the computer has become a dominant feature in our lives and is displaying ever increasingly human characteristics.

This growing humanity is not necessarily a matter for joy as the previous 'Man of the Year' was Ayatollah Khomeini. Some of the letters in the following issue of Time (24 Jan. 83) revealed the concerns about the computer:

'It is appropriate that a machine should replace the Man of the Year in 1982, especially when one considers the colossal absurdity of the times in which we live.'

'I am dismayed that the computer alone is Man of the Year. The title should be shared equally with unemployed Americans. The computer is the big reason why so many Americans are jobless.'
'I fear computers will start World War III by mistake. They now make errors on income tax, bank statements and utility bills. These machines have no conscience.'

'You have only encouraged them - the juvenile administrators who attempt to solve management problems with technological toys rather than study, analysis and wisdom.'

'Congratulations on your choice of the computer. You have selected my livelihood, my friend and, according to my wife, my constant companion.'

I suppose my main concern as a businessman sitting on top of a large gold mining operation which makes considerable use of the computer, is whether this hardware makes up for the frailties of man or simply compounds them. The fact that we now have to have a conference on the computer and internal audit seems to suggest that the computer serves to multiply our capacity for mistakes and malpractices!

But to be more serious, the computer is obviously an important focus for internal audit and can also be its best atly. This involves however not only an understanding of the computer by those responsible for internal audit but also an understanding of internal audit by the computer people. If the audit process is to be really effective, training of those involved with the computer must begin at the systems development level. While the computer is now an integral feature of business life, internal audit has only recently begun to be properly appreciated in South Africa. This is partly because of the arrival on the scene of the computer, but also because of the growing complexity of business and the felt deterioration in supervisory and managerial talent which is a qualitative as well as a quantitative problem.

I believe that an increasing number of executives understand that internal audit has gone far beyond the 'policeman' or 'spy' activity and far beyond the simple processes of ticking and counting. I think also that it is more readily understood that internal audit is not an extension of external audit and that while the function of the latter is to report to the members of a company who are, in a sense, outside it, the function of internal audit is to satisfy and assure the management. Increasingly, internal audit is being used to identify problems, to test systems and to evaluate internal controls. It is the C.E.O.'s alter ego it tells him how well his objectives, policies, plans and instructions are being carried out and how effectively and efficiently his controls and operations are working.

Hugh Marsh of ALCOA USA, said of internal audit: 'I believe that the most important benefit to be provided by internal audit to management is providing comfort. And that comfort can be directly related to the auditor's scope of work: first, that $I$, as a manager, have been working with reliable data; secondly, that my employees are complying with policies, plans, procedures and government laws and regulations; thirdly that my assets are being properly safeguarded; fourthly, that I am using resources economically and efficiently; and finally, that my objectives and goals are truly being achieved.'

The Attorney General of Canada calls internal audit: 'One of the sharpest and most effective tools available to management to ensure that it manages the resources for which it is accountable economically, efficiently and effectively.' 
We are perhaps lagging behind in South Africa in so comprehensive an understanding of internal audit but I believe this is growing and will become common practice within a few years. Few big organizations are without it though one large institution with which I am associated outside the mining houses is only now installing an internal audit system. Our need is as great as anywhere in the world because our society is equally imperfect and human frailties no less evident - 'We are not a society of saints'.

It is nearly four months ago that, in my capacity as President of the SAIM, I said in the course of a speech in Port Elizabeth that business and public administration in South Africa were shot through with dishonesty. This statement caused quite a stir at the time and for a couple of weeks thereafter and, apart from the news items, editorials and letters in the newspapers, I was bombarded with phone calls and letters, anonymous and open.

I have no wish to become more deeply embroiled in this matter but feel the need to make further reference to it and this address provides a better vehicle than most. My purpose is to acknowledge that many people of all sorts and ranks in society have gone out of their way to thank me for raising the matter and contributed further to our knowledge of it. I wish I could say that I now feel that I exaggerated the problem back in November. Some of my friends in chief executive positions have suggested to me that I did exaggerate the problem. They are men of great personal integrity running large organizations employing thousands of people. It seems that they simply do not know - and cannot hope to know - what is happening further down the line, often in their own organizations, let alone others. Regrettably the general message is that corruption of one sort and another is indeed widespread in the public services, parastatal organizations, boards, local authorities and in business, much more so than $I$ realized. This has been confirmed by chief executives on the one hand and clerks and junior officials on the other. Sector after sector of our society has had the finger pointed at it by someone who knows his facts. Not all the accusations have suffered from vagueness which often characterizes this sort of problem - a number have been pretty specific and detailed. I do not set myself up to be an ombudsman and therefore have, generally speaking, not taken these any further.

It is abundantly clear that a great many of the actions which result in personal gain at the expense of the institution are based on collusion between someone employed by the institution and someone on the outside, usually a supplier of equipment and goods or a contractor providing services, repairs and the like. Between them they collude to rob the institution by falsifying the financial arrangements between the two bodies they represent with a very good chance of their collusion not being detected. There are, inter alia, many examples of tender procedures - probably thought by management to be sound and foolproof - being manipulated by collusion to the benefit of the unscrupulous parties.

I would like to quote from some of the letters I have received, none of these being anonymous, but being properly signed by the writer.

The first is from a managing director:

'From my experience I have found several reactions:

- There's something wrong with me for not accepting "extras";

- There's something wrong with my company for not offering "extras";

- Rocking the boat when I observe this practice creates a blacklash and permanent damage to my company.

I'm frustrated with this situation. My personal experiences in (he mentions three third world countries) has given me an insight into the logical extension of such practices.'

And a woman who works in her husband's business:

'I have always taken the view that payments of this nature are nothing other than bribery but I'm afraid my adamant attitude has lost my husband a great deal of the more lucrative type of business. When I see how much the harder he has to work in order to maintain this ideal of honesty, my heart aches and I don't know whether I am right to be so rigid.'

A similar statement from another manager:

'It has been disappointing in this last 13 years in South Africa to have experienced situations whereby because of my personal principles I would not stoop to graft. The consequences of lost business although hurtful and unprofitable at the time resulted in a clean conscience . . . Corruption needs harsh treatment actioned by all . . . our strength to eradicate graft will only come from unity of effort.'

And finally, a man who retired from a senior buying position a few years ago:

'I have (since retiring) met many people associated in one way or another with the mining industry and the stories I have heard indicated a serious worsening of the situation.'

I do not like anonymous letters but I am now going to add something said by an anonymous person because it may be much more relevant to a 'worsening situation' than we realize. His view was that the Info scandal and particularly the many aspects of it left unresolved, involving very important people in public service and in business, created the environment in which lesser people felt that corrupt practices at their level were, if not defensible, at least not without the precedent of top-level example.

In fact, the most serious aspect of the whole matter is the view that corrupt practices are so widespread because they involve some top level people in various sectors who are in one way or another shielded from public gaze. Alternatively that there are many top people who appear to know what is going on but are not prepared to speak out or take action for one or another reason.

Just another word on anonymous letters and phonecalls. Most of these dealt with a specific issue and often named those alleged to be involved. One which arrived on my desk in January is worthy of mention. While it is on plain paper, it purports to come from 'an extremely large Group of Companies', is well-typed and purports to have been written by senior executives. It deals with irregularities within our Group, particularly one gold mine, and says they will be watching developments with interest and 'consider taking other relevant action if this highly unsatisfactory state of affairs be allowed to continue'.

Should those who wrote this letter hear of my reference to them now, I trust they will realize that this is a silly way for 'an extremely large Group of Companies' to behave and that their statement that 'unfortunately for reasons which will be self-evident we must write to you anonymously' is quite unacceptable. One of the executives could have seen 
me or they could have written confidentially but openly to me. Frankly, this letter is in itself a form of corruption and I can only hope that the authors are not who they pretend to be. If they are indeed senior executives of a large group, I hereby issue them with an invitation to see me confidentially with an undertaking that if they have been playing the game straight, they have no reason to fear reprisals or whatever it is they fear.

Perhaps this is the apposite point at which to say that it is also evident that some innocent people are accused or kept under suspicion for practices of which they are innocent. After all, the majority of people in all sectors are innocent and some have to suffer from unfounded accusations. This is one of the aspects that causes people to hold back in bringing corruption to the fore - and quite rightly so. The legal principle that a man is innocent until he has been proven guilty should especially apply in the matter of business ethics.

I have been watching the newspapers over the last four months for new evidence of corruption, graft and mismanagement of funds and this there has been in fair abundance, with a comforting number of these matters reaching the courts. Inter alia, the press has given considerable attention in recent months to alleged acceptance of 'gifts' by medical officials from one or more pharmaceutical companies. At the same time, other press reports have reinforced the fact that the problem of corruption is by no means confined to South Africa or to the free enterprise world but is endemic in the whole of today's world. In fact, the absence of entrepreneurial opportunities in socialist and communist countries appears to create even worse problems in those countries. A new book by Patrick Meney, a French journalist who was a correspondent in Moscow for years, says the Soviet Union has become a kleptocracy - 'a society of thieves, fixers and conmen' (Star 8 Jan. 73). The highest and the lowest in the land are included in this kleptocracy and in a black market where prices are usually ten times higher than the normal ones. He cites the case of the Minister of Fisheries who headed a ring flogging tons of caviar abroad annually by exporting the rare delicacy to accomplices in Switzerland as tinned herrings. The Minister's resignation in 1979 led to the arrest of 200 dishonest officials. He also tells of the 'factory that never was' which enriched those who connived to pay salaries and subsidies to non existent officials.

The new President of Mexico, de la Madrid, where corruption has long been endemic has embarked on 'moral renovation'. Inter alia he is seeking changes to the constitution that will make it easier to prosecute corrupt officials. In an article in Time, 20th December, some doubt is expressed about de la Madrid's ability to bring about his moral renovation because 'the country's effective one-party system virtually institutionalized the practice (of corruption), a fact that Mexicans have recognized with equanimity'. Among other things, 'Mexicans suspect that as many as one million phony jobs were created in the country's economy, while government officials and others siphoned off the paycheques for non-existent workers.'

McGraw-Hill, the vast American publishing company has conducted a survey of business ethics in 16 industrialized countries. I have not seen the actual survey and have to rely on a recent press report. Apparently the survey showed that one senior manager in seven gets caught up in unethical business practices, including bribery and falsification of in- formation. More than half of the 900 executives questioned had recently been confronted with at least one conflict between the demands of their company and their personal beliefs of what is right. One in ten had been faced with having to take an unethical decision at least six times during the previous five years. Thirty-eight percent of those questioned admitted they had recently either made or received an irregular payment of one kind and another. Finally, the survey states that two-thirds of those who acted according to their consciences and refused to comply with unethical company dictates suffered no adverse consequences at all.

These examples of corruption in other countries are not given to turn the spotlight off our own problems and while it is a comfort, cold though it may be, that other countries have even worse corruption and that socialism and Marxism are more corrupt than capitalism, the matter of real concern is what is happening here in South Africa.

The overall picture has perhaps best been expressed in a brief editorial in The Star on 9th November, 1982, which is worth quoting in full:

'Only the most naive would have been surprised by Mr Dennis Etheredge's lament that business and public administration in South Africa are shot through with bribery, kickbacks and plain fraud. Corruption rocks not just the capitalist world but the communist and the Third World too. Nor can it be blamed on 20 th century immorality. It has been a way of life for many ever since money and services became part of civilization. Today some large companies budget for kickbacks; some Third World governments deliberately underpay public servants knowing they make up for it "informally", some communist countries are crippled with bureaucratic graft. Perhaps Mr Etheredge's cry of frustration will lead to something. But only perhaps. Corruption is held in check only by the vigour of a society's nonmaterialistic values.'

I want now to be constructive and suggest what can be done to reduce the incidence of corrupt practices in our society. Some of the ideas which follow have originated from other people who have made contact with me since the Port Elizabeth spech. The ideas group themselves under four headings:

\section{Legislation}

I am convinced that not all problems are solved by legislation and that our politicians are already too fond of adding to the mass of laws which govern our lives. In fact, one of the problems of private enterprise in South Africa which claims to be a bastion for this system, is that our legislators have wrapped it up within such a maze of laws, control boards, administered prices and general state interference that it is a wonder that it works at all.

However, we need to take note of the important impact in the United States of the Foreign Corrupt Practices Act which came into being in 1978 to cope with widespread questionable corporate payments to foreign officials and businessmen. It goes much wider than its title suggests and provides comprehensive accounting provisions which along with the anti-bribery provisions operate regardless of whether a company is involved in overseas business. Naturally, the act was not well received nor is it without its confusing aspects but is has led to substantial changes in company behaviour and practices and has reinforced the 
system of audit committees of the Board of Directors. These audit committees operated in about two-thirds of companies in the USA in the early 70s but since the passing of the Foreign Corrupt Practices Act there is hardly a company which does not have an audit committee of directors, involving the outside directors of the company. Such an Audit Committee not only lends weight to both internal and external audit; it recognizes the fact that the problems which arise often involve those at management levels as well as those they supervise.

Perhaps I have put the last, first - legislation might be avoided if some of the other suggestions which follow are implemented. Nothing should give us greater pleasure than avoiding the necessity for the passing of another law.

\section{Behaviour}

We need to change the attitude in our society towards corrupt practices, big and small, especially amongst those in positions of responsibility. During the war 'up North' we used to talk of 'organizing' things for ourselves - petty stealing to make life more tolerable. That might have been acceptable behaviour in the peculiar circumstances of the time but it is apparent that in many areas of our society it is still acceptable. Remember that what we are talking about is stealing in one form or another - stealing from the company, stealing from the State. We cannot reduce the incidence of this if we shrug our shoulders and say it is inevitable. We ought in every organization to have a code of practice and to provide severe penalties for those who transgress the code. It is still the practice in many places to fire quietly an employee who has been guilty of fraud or some other malpractice; fortunately, in a growing number, the matter is also handed over to the police.

Prosecution often presents difficulties. Many a man who will tell you privately what he knows about a particular malpractice amongst his associates will not agree to make a sworn statement because of the embarrassment and perhaps victimization that will follow. I am aware of a number of cases where the absence of just one such statement meant that a prosecution was not possible. Again, one is faced with a problem of behaviour in a society. Management must do all it can to inculcate an understanding that it is incumbent upon employees to help in the prosecution of someone who is clearly guilty of malpractice. It may sound harsh but it is true that someone who fails to do this is himself something of an accessory to the crime. Of course, where assurances can be given that there will be no comebacks and no victimization they must be genuinely given.

Some businesses do not spell out clearly enough what they accept as legitimate behaviour and what is not. In November last year, Assocom helped member firms with the issue of guidelines which include instant dismissal as an automatic penalty for employees guilty of graft. This is a policy already followed by a good number of companies but it needs to be universally applied - and in the public services as well.

The S.A. Institute of Management's Code of Conduct which was issued in book form to all members in 1982 makes three references to business ethics:

- 'A manager shall not misuse his authority or office for personal or other gain' and,

- 'Make immediate and full declaration of any personal interests which may conflict with the interests of the organisation' and,

- 'Neither offer nor accept any gift, favour or hospitali- ty, intended as, or having the effect of, bribery and corruption'.

Gifts can, of course, be made to private and pubiic employees if it is absolutely clear that they are not intended or have the effect of bribery and corruption. In fact, in the same issue of the Sunday Express which revealed what was happening in the medical world, there was an article 'Executives get gifts - not bribes' which said the executive gifts industry was booming with growth estimated this year to be $20 \%$ up in a market estimated at $\mathrm{R} 200 \mathrm{~m}$. The chairman of a group in this field is quoted as saying that 'Attitudes have changed and managements accept that it is now normal practice, within reason, for companies to exchange gifts simply to say thank you for an association.' I suppose the critical words here are 'within reason'. In the circumstances it is comforting to know from him that the most common gifts, ranging from $50 \mathrm{c}$ to $\mathrm{R} 100$ are imprinted ones. If our problems were limited to $50 \mathrm{c}$ to $\mathrm{R} 100$ there would be little cause for concern but unfortunately it runs into far larger figures, sometimes five and six figures.

None of those who extol the virtues of the private enterprise system here or elsewhere pretend that it is perfect. While one can declare without doubt that private enterprise is the best way to bring about growth and development and to motivate people, one has to admit that it has its blemishes and that unscrupulous individuals have opportunities to misuse it. Not only do we in the private sector understand this but I believe that much is being done to make corrupt practices more difficult and to lift the level of business ethics. It is not unreasonable therefore to suggest that the Civil Service, parastatal bodies, control boards and local authorities should have a good look at themselves, taking account of widespread allegations of mishandling of funds in a variety of ways. To those of us on the outside, the much-publicized rationalization of the civil service seems to have done little to improve the service it is supposed to provide. We are faced with the cry that the Civil Service has serious shortages of personnel - which is certainly true in certain key areas - but we are also aware that the State employs a very high proportion of the white population about $30 \%$ I think it is.

But I am not trying to play down the seriousness of staff shortages. The Sunday Express (23 Jan. 83) reported that most senior Government and Army men who appeared before the 1982 Parliament Select Committee on Public Accounts complained of inability to comply with auditing regulations because of critical staff shortages. If stock cannot be checked, and vouchers confirmed the possibility of corrupt practices is greatly increased.

We have also heard in the press about the vast number of vacancies in the Inland Revenue Department which inevitably means some taxes are not being collected and opportunities for evasion are increased. Business Times quoted on 21 st January a top of ficial of Inland Revenue who said:

'Don't quote me, but our calculations suggest that,

as things stand, the professional tax dodger has a

$40 \%$ greater chance of making $70 \%$ more money

over 10 years than the honest and consistent taxpayer'.

Apart from the problem of staff shortage and inadequate audits, the public services are missing another important discipline. Other than in the case of some parastatal bodies, there is no profit motive, no bottom line and no danger of 'going bust'. Sloppy practices are much easier than in the 
private sector where audits are regularly and fully carried out and everything has to be tuned to the overall necessity of making a profit.

\section{Education}

In the long term, we must rely on educating and re-educating our society. In the field of business education, I am pleased to state that the graduate schools of business are discussing the inclusion of a course in business ethics in the MBA. The GSB at UCT already offers a course which goes some way towards this - 'Business in Society: concepts and values in an African context' developed and taught by Dr James Leatt. I appreciate that a great amount has to be squeezed into an effective business course but believe that there must be room to prepare the potential senior manager and chief executive for the fact that we are not a society of saints.

It seems that there is also a need for a course in medical ethics in our medical schools if one is to take into account a recent article by Jill McIlwrath in the Sunday Express (13 Mar. 83). She reports on the indifference of medical students towards the recent revelations in regard to the relationship between some doctors and some pharmaceutical companies. She says:

'The failure of many students to see the relationship with commercial interests as one aspect of the many ethical issues they will face when they practice must be a cause for concern by all those in the profession who do wish to safeguard high ethical standards in medicine and those in the receiving end of doctors' care, the patients.'

In the wider sense, education in the home and the school is clearly of the greatest importance. We have to build up and entrench what The Star editorial called 'society's nonmaterialistic values'. We have to see that in the education of our children we really live up to the claim so often made that we are a Christian society. We have to inculcate in them a belief that good principles are worth adhering to and that corrupt practices are morally indefensible. Business ethics which term covers not just the business world but all other economic activity as well - must be seen as central to a worthwhile society.

Dr Leatt says of it in a recent article:

'Business ethics is more than blowing the whistle on dishonesty and graft. It is disciplined reflection upon what constitutes right as opposed to wrong actions. In the business context, ethics can be defined as a concern with the way people choose between significant alternative courses of action. Nearly all weighty decisions in business are value-laden, that is, they involve making judgements which are not based solely on factual information but on what is considered right in specific situations.'

\section{Audit}

I have left audit to the end. Clearly the audit process provides the best means of dealing with corrupt practices. I am thinking particularly of internal audit in the terms to which I referred to it towards the beginning of this address as the identifier of problems, the tester of systems and the evaluator of internal controls. If it is to do this, management must install the systems and the internal controls and must ensure that the internal audit team is composed of high quality people and is not deviated from its proper task. As a general rule, the more the business is run on the basis of clearly defined systems and controls, the less opportunity there is for employees to break the rules to feather their own nests. While I recognize that the computer brings its own security problems, it is undoubtedly a major aid in reducing opportunities for self-seeking behaviour.

One young chartered accountant in Johannesburg who has bumped against 'modern business corruption' points out that external and internal audit only bring real benefits if the business is already effectively managed and operated. In the case of external audit, checking for dishonesty among employees is only a secondary function while internal audit too easily 'becomes a rubber-stamping of the paper shuffle, combined with a periodic stock verification and so loses much of its credibility and effectiveness'. He therefore proposes something new - an external operational audit which he defines as 'the systematic analysis of individual activities at an operational level on a time/item random selection basis'. It would be aimed primarily at deterring employees from misusing their positions for personal financial gain. Such an operational audit team would not be composed solely of accountants but would include engineers and others who understand those operations where abuse and collusion is likely to occur.

While this proposal has some faults, it is worth following up and as I cannot devote more time to it in this address, I will provide anyone interested with the name and telephone number of the author. Other audit arrangements have also been suggested at one time or another. Some of my callers in the last few months have suggested that the ombudsman activity should be greatly strengthened so that there is a channel through which charges of perceived corruption can be directed. The F.B.I. in Hillsborough Country, Florida, asks citizens to dial $229-9241$ which is their 'corruption hot-line' installed after three of the five county commissioners were charged with conspiring to extort money from citizens seeking approval for zoning applications. The hot-line operates 24 hours a day and received calls from 140 citizens in its first week of operation.

Hotlines, ombudsmen, internal audit, education, legislation - so many possibilities and combinations, good and bad, but what is abundantly clear is that something must be done. 